\title{
Phosphoglycerate Mutase 1
}

National Cancer Institute

\section{Source}

National Cancer Institute. Phosphoglycerate Mutase 1. NCI Thesaurus. Code C132327.

Phosphoglycerate mutase 1 (254 aa, 29 kDa) is encoded by the human PGAM1 gene.

This protein is involved in the interconversion of 3- and 2-phosphoglycerate during glycolysis. 